\title{
ŚRODOWISKO JAKO KATEGORIA
} PEDAGOGICZNO-EKOLOGICZNA

\section{ENVIRONMENT AS PEDAGOGICAL AND ECOLOGICAL CATEGORY}

\section{Streszczenie}

Środowisko naturalne osoby ludzkiej tworzy płaszczyzna przyrodnicza (w której jest pokarm), społeczeństwo (w którym jednostka żyje) oraz sama osoba stanowi dla siebie środowisko. Celem artykułu jest wyjaśnienie pedagogiczno-ekologicznych implikacji środowiska społeczno-przyrodniczej przestrzeni człowieka - jako kategorii badań naukowych humanistycznie zorientowanej filozofii społecznej (modelu badań jakościowych w kategoriach filozoficznych).

\section{Stowa kluczowe}

Środowisko, wychowanie do ekorozwoju, wychowanie ekologiczne, ekologiczna samorealizacja.

\section{Summary}

Natural environment of a human being consists of natural ground (where one can find food) and a society (in which one lives). Additionally, the person constitutes his or her own environment. The aim of this article is to explain the interdisciplinary implications of the environment of social and natural spheres of a human being - as a category of scien- 
tific research of humanistically oriented social philosophy (a model of quality research in philosophical categories).

\section{Key words}

Environment, education for eco -development, ecological upbringing, ecological self - fulfillment.

Człowiek jest przeto zmuszony do życia na podłożu Przyrody $i$ w jej obrębie, lecz dzięki swej szczególnej istocie musi przekraczać jej granice, ale nigdy nie może w petni zaspokoić swej wewnętrznej potrzeby bycia człowiekiem.

Roman Ingarden

\section{WPROWADZENIE}

Środowisko ${ }^{1}$ tworzy ogół czynników otoczenia (rzeczy, procesów, zdarzeń), które mają wpływ na dany obiekt i (lub) pozostających pod jego wpływem. ${ }^{2}$ Środowisko to termin odmiennie definiowany w poszczególnych dyscyplinach naukowych. W ujęciu socjologicznym jest otoczeniem ${ }^{3}$ społecznym, w którym żyje jednostka. W myśl humanistycznie zorientowanej filozofii społecznej - modelu badań jakościowych w kategoriach filozoficznych istotne są ludzkie losy, indywidualne doświadczenia, subiektywne oceny i emocje. Według Floriana Znanieckiego należy środowisko ujmować oraz interpretować w kategorii środowiska społecznego danego osobnika, a więc środowiska niepowtarzalne-

\footnotetext{
${ }^{1}$ Pojęcie „środowisko” etymologicznie pochodzi z j. greckiego od słowa oikos dom, środowisko, siedlisko, domostwo, miejsce życia.

2 Stownik terminologiczny informacji naukowej, Wrocław 1979, s. 112.

${ }^{3}$ Natomiast według R. Wroczyńskiego środowisko nie jest równoznaczne o otoczeniem, ponieważ środowisko tworzą te elementy, które wywierają realny wpływ na daną jednostkę - nawet jednorazowa styczność bezpośrednia może mieć większy wpływ na jednostkę, niż trwałe interakcje społeczne.
} 
go, które tworzą jednostki, grupy społeczne, ${ }^{4} \mathrm{z}$ którymi dana jednostka (osobnik) styka się (prywatnie, publicznie, bezpośrednio, pośrednio, przelotnie, trwale, osobiście, rzeczowo) w ciagu swojego życia.

\section{ROZWÓJ CZŁOWIEKA, LUDZKOŚCI I ŚRODOWISKA}

Jeden z najwybitniejszych filozofów amerykańskich, przedstawiciel progresywizmu pedagogicznego - John Dewey (pragmatyzm filozoficzny) twierdził, ${ }^{5}$ że indywidualny rozwój człowieka przypomina rozwój ludzkości. Rozważając wpływ czynników na rozwój człowieka, Dewey podkreślił, iż trzeba brać pod uwagę czynniki środowiska społecznoprzyrodniczego, realizując koncepcję uczenia się przez działanie (learning by doing). W ujęciu Deweya - filozofia jest teorią wychowania w najszerzej pojętych aspektach świadomego kierowania praktycznym działaniem. ${ }^{6}$

Środowisko jako przestrzeń życiowa człowieka implikuje całokształt czynników biologicznych, społecznych, materialnych. Wyodrębniono środowisko biologiczne, które determinuje życie i rozwój organizmów biosfery; środowisko geograficzne - związane z położeniem na obszarze kuli ziemskiej; środowisko kulturowe stanowiące zbiór dóbr (w zakresie pozytywnego i negatywnego statusu dziedzictwa kultury), które wpływają na kształtowanie się ludzkich postaw wobec środowiska społeczno-przyrodniczego; środowisko społeczne, ${ }^{7}$ które tworzą jednostki, grupy społeczne - wywierające wpływ na aktywność człowieka w sieci instytucji życia społecznego (usługowe, administracyjne itp.). Środowi-

${ }^{4}$ F. Znaniecki, Metoda socjologii, Warszawa 2008, s. 68 i nast.

5 Podobnie jak Ernst Haeckel, który w 1866 roku wyodrębnił pojęcie ekologia.

${ }^{6}$ J. Dewey, Jak myślimy?, [w:] S. Wołoszyn (red.), Źródła do dziejów wychowania i myśli pedagogicznej, t. III ks. I: Myśl pedagogiczna w XX wieku, Kielce 1998, s. $127-128$.

7 Środowisko społeczne - jako grupa osób, które mają wspólną kulturę, zajmują określony obszar terytorialny i mają poczucie przynależności do odrębnej całości. Przy czym można wyodrębnić społeczeństwo otwarte i społeczeństwo zamknięte na zmiany. Te pojęcia wprowadził Karl R. Popper w książce pt. Społeczeństwo otwarte i jego wrogowie (1945). 
sko stanowi całokształt mniej lub bardziej trwałych warunków świata zewnętrznego, w którym dany organizm żyje, do których się przystosowuje, wywołując dwustronne przemiany (wzajemna współzależność) $\mathrm{w}$ organizmie i w jego środowisku. ${ }^{8}$

Środowisko naturalne jako obszar ludzkich działań je zmieniających - stało się kategorią w badaniach naukowych ekologii dopiero w XX wieku. Chodzi o badania dotyczące znaczenia środowiska przyrodniczego w rozwoju człowieka oraz form zależności człowieka od środowiska naturalnego. Na gruncie nauk społecznych, zwłaszcza socjologii wsi badania ekologiczne zainicjował Charles J. Galpin (1915) oraz naukowcy tzw. „szkoły chicagowskiej.”9 James A. Quinn wyodrębnił interakcję ekologiczną w odróżnieniu od interakcji społecznej. Robert E. Park w swoich publikacjach uzasadniał analogie zachodzące między ekologią człowieka a ekologią zwierząt i ekologią roślin. ${ }^{10}$ Natomiast twórca ekologii kulturowej Julian H. Steward wyjaśnił, iż „...człowiek wchodzi na ekologiczną scenę (...) nie tylko jako (...) organizm pozostający $(\ldots) \mathrm{w}$ określonych stosunkach z innymi organizmami (...) wprowadza ponadorganiczny czynnik kulturowy"11, który ewoluuje wieloliniowo i jest uwarunkowany czynnikami ideologicznymi, ekonomicznymi, politycznymi.

N. Wolański uogólnił, że ewolucja człowieka postępowała wieloma ścieżkami według następującej sekwencji: biologiczną, społeczną, kulturowa. Przy czym społeczna i kulturowa sfera ludzkiego życia stanowi pochodna jego biologicznych właściwości (kultura stabilizuje biologiczną istotę ludzką). ${ }^{12}$ Człowiek znajduje się na granicach bytów: przyrody i specyficznie ludzkiego świata, ${ }^{13}$ który jest składnikiem praw

\footnotetext{
8 J. Pieter, Stownik psychologiczny, Katowice 2004, s. 307.

9 „Szkoła chicagowska” - to grupa badaczy skupiona (od 1915 r.) wokół Roberta E. Parka (1864 - 1944) na założonym w 1892 r. Wydziale Socjologii i Antropologii Uniwersytetu w Chicago.

10 J. Szacki, Historia myśli socjologicznej. Warszawa 2002, s. 602.

11 Tamże, s. 681.

12 N. Wolański, Ekologia człowieka, t. 2: Podstawy ochrony środowiska i zdrowia człowieka. Ewolucja i dostosowanie biokulturowe, Warszawa 2008, s. 45.

13 R. Ingarden, Ksiqżeczka o człowieku, Kraków 2009, s. 17.
} 
przyrody. Cierpienie jest nieodłącznym - według Jana Szczepańskiego - atrybutem życia. W przyrodzie muszą ginąć rośliny, by inne rośliny, zwierzęta i ludzie mogli żyć; muszą ginąc zwierzęta, by inne zwierzęta i ludzie mogli żyć. ${ }^{14}$

Ekologia to „nauka o współzależności oddziaływań organizmów $\mathrm{z}$ ich środowiskiem życia abiotycznym (fizycznym ${ }^{15}$ ) i biotycznym (innymi organizmami, także ludźmi); w ramach tych interakcji wyróżnia się poziomy oddziaływań: osobniczy, populacyjny (głównie zmiany liczebności), biocenotyczny (zespoły konkurujących populacji na danym terenie) ekosystemowy (krążenie materii, sieci pokarmowe, przepływ energii)." ${ }^{\prime 6}$ Ekologia powstała w II połowie XIX wieku jako nauka przyrodnicza. ${ }^{17}$ Stała się źródłem ekologii człowieka ${ }^{18}$ rozumianej jako interdyscyplinarna wiedza o człowieku i jego kulturze - komponencie ekosystemów. Przedmiotem badań ekologii człowieka jest interakcja w systemie ekologicznym, którego centrum stanowi populacja ludzka. Bada biologiczne, społeczne i kulturowe przystosowanie człowieka do środowiska na poziomie osobniczym i populacyjnym, ${ }^{19}$ a więc także

14 J. Szczepański, Sprawy ludzkie, Warszawa 1984, s. 242; por. tenże, Wplyw kultury na życie społeczne, [w:] H. Mielicka (red.), Socjologia wychowania. Wybór tekstów, Kielce 2000, s. 69.

15 Środowisko abiotyczne tworzą: m. in. światło, woda, gleba, gazy atmosferyczne, temperatura, wilgotność, prędkość wiatru, rzeźba terenu, kwasowość gleby.

16 N. Wolański, Ekologia człowieka, t.1: Podstawy ochrony środowiska i zdrowia człowieka. Wrażliwość na czynniki środowiska i biologiczne zmiany przystosowawcze, Warszawa 2008, s. 453.

17 Zob. przegląd definicji ekologii jako nauki przyrodniczej, [w:] M. Wyrostkiewicz, Ekologia ludzka. Osoba i jej środowisko z perspektywy teologiczno-moralnej, Lublin 2007, s. 23-31.

18 Człowiek jest elementem biosfery - należy do gatunku lądowych ssaków. Nie może pić wody morskiej, odżywia się heterotroficznie (wszystkożerny: rośliny, zwierzęta), optymalna temperatura otoczenia: $25^{\circ} \mathrm{C}$, prowadzi życie stadne. Nie można na istote ludzką patrzeć jedynie w kategoriach biologicznych - przyrodniczych, lecz brać trzeba także pod uwagę ludzkie postawy (kształtowane na fundamencie systemu wartości) wobec środowiska życia. Człowiek stanowi przedmiot badań wielu dyscyplin naukowych - zwłaszcza antropologii, która zajmuje się człowiekiem w aspekcie biologicznym, filozoficznym, społeczno-kulturowym, teleologicznym (wiedza interdyscyplinarna).

19 N. Wolański, Ekologia człowieka, t. 1: Podstawy ochrony środowiska i zdrowia człowieka. Wrażliwość na czynniki środowiska i biologiczne zmiany przystosowawcze, Warszawa 2008, s. 45; por. L. Agapow, A. Kładna, J. Kruk, R. Feruszewski, Ekologia 
w zakresie tworzenia wzorów stosunków społecznych przez grupy społeczne - adaptujące się do swego środowiska (mechanizmy adaptacyjne).

Mimo, że ekologia jest młodą dyscypliną naukową świadomość więzów łączących człowieka ze środowiskiem naturalnym - w poznaniu potocznym - towarzyszyła od zawsze. Postulat myślenia w kategoriach ekologicznych dojrzewał przez stulecia - do rozkwitu przesłanek dla uogólnień naukowych. W przypadku kultury polskiej - począwszy od pierwszych zarządzeń królewskich w X wieku ${ }^{20}$ (które miały na celu ochronę terenów łowieckich i lasów) oraz postulatów życia w zgodzie $\mathrm{z}$ przyrodniczym rytmem pór roku, ${ }^{21} \mathrm{z}$ uzasadnieniem, że nie można występować przeciwko naturze (,...przyrodzenia nikt gwałcić nie może..."). ${ }^{22}$

Pochwałę życia zgodnego z naturalnymi prawami przyrody - w antropocentrycznej kulturze epoki renesansu - głosił Łukasz Górnicki „natura jest matką wszystkiego dobra, ${ }^{23}$, ,natura zawdy ku doskonałości zmierza." ${ }^{24}$ Również Jan Kochanowski uzasadnił terapeutyczny wpływ przyrody na zdrowie człowieka i jego egzystencję w środowisku naturalnym. ${ }^{25}$ Natomiast mieszkający w Polsce słynny pedagog Jan Amos Komeński w swoich publikacjach podkreślił związek życia ludzkiego z prawami naturalnymi w otoczeniu przyrodniczym. Zachęcał nauczycieli, aby nauczać (uczyć się) obserwować i naśladować przyrodę i podobnie, jak „potrzebuje drzewo w pewnych odstępach czasu odpoczynku (...) tak, aby nie musiało ono ciagle silić się na wydawanie ze siebie pączków, nowych kwiatów, czy owoców, lecz mogło czasem także dla siebie (...)

czlowieka, Szczecin 1998, s. 10; Z. Chromiński, A. Malinowski, Ekologia człowieka, Warszawa 2001, s. 5; Z. Jethon, Ekologia czlowieka w wychowaniu fizycznym i sporcie, Wrocław 1994, s. 3-4; Z. T. Wierzbicki, Ekologia człowieka a sozologia, Wrocław 1982, s. 66; S. Żmuda, Zarys ekologii człowieka, Kraków 1983, s. 15.

20 W. Hensel, J. Pazdur (red.), Historia kultury materialnej Polski w zarysie, t. 1: Od VII do XII wieku pod red. M. Dembińskiej i Z. Podwińskiej, Wrocław 1978, s. 112.

21 M. Rej, Żywot człowieka poczciwego Wrocław 2003, t. 1, s. 403.

22 Tamże, s. 595.

23 Ł. Górnicki, Dworzanin polski, Wrocław 2004, t. 2, s. 127.

24 Tamże, s. 318.

25 Por. fraszki: Na lipę, Do pszczót, Do gór i lasów, Na dom w Czarnolesie. 
pracować, przetrawić soki, i w ten sposób wzmacniać własne siły. Kazał przeto Bóg, by po lecie następowała zima, aby zapewnić odpoczynek wszystkiemu, co wyrasta z ziemi, a przez to i ziemi samej." 26

W europejskiej kulturze intelektualnej epoki oświecenia rozważano miejsce człowieka w środowisku naturalnym. Według Denisa Diderota - redaktora trzydziestopięciotomowej Encyklopedii albo słownika rozumowanego nauk, sztuk i rzemiost - przyroda jest źródłem doskonałości, a prawo natury - prawdziwe. Woda, powietrze, ziemia, ogien - wszystkie żywioły mają znaczenie i miejsce w systemie przyrody, którego prawa ma badać filozofia. Filozof naturalista, współtwórca encyklopedii - Paul H.D. Holbach wyjaśnił, że przyroda stanowi zorganizowaną całość - implikuje wszystkie byty, a człowiek jest bytem poddanym determinantom przyrody. Z francuskimi encyklopedystami współpracował przejściowo wybitny filozof oświecenia Jean Jacques Rousseau. W dziele pt. $O$ umowie społecznej podkreślił wartość wolności, ${ }^{27}$ wyjaśnił, że szczęśliwy może być człowiek, który „nie jest uwikłany w cywilizację", a więc życie społeczne powinno rozwijać się w stanie zbliżonym do naturalnego pierwowzoru. ${ }^{28}$ Rousseau apoteozował środowisko naturalne, stwierdził: „wszystko, co dobre, kiedy wychodzi z rąk Stwórcy - wyradza się w ręku człowieka", ${ }^{29}$ przyroda jest radością człowieka. Postulował, aby „długo podglądać przyrodę”, wychowywać dzieci w zgodzie z prawami naturalnymi, ponieważ natura kształtuje człowieka fizycznie a wychowawcy moralnie. ${ }^{30}$ Porównywał wychowanie dziecka do troskliwej uprawy ${ }^{31}$ darów naturalnych środowiska przyrody.

Wybitny twórca myśli pedagogicznej przełomu XVIII i XIX w. Johann H. Pestalozzi także rozważał miejsce człowieka w środowisku jego ży-

26 J. A. Komeński, Wielka dydaktyka, Warszawa-Lwów 1935, s. 101.

27 J. J. Rousseau, O umowie społecznej, Kraków 1927, s. XVII.

28 Tamże, s. 1; por. J. Parandowski, Rousseau. Szkic literacko-filozoficzny, Lwów 1913, s. 52.

29 J.J. Rousseau, Emil czyli o wychowaniu, Lwów-Warszawa 1930, cz. 1, s. 5.

30 J. J. Rousseau, Emil czyli o wychowaniu, Lwów-Warszawa 1933, cz. 2, s. 85.

31 J. J. Rousseau, Wybór tekstów pedagogicznych, Warszawa 1949, s. 32. 
cia. ${ }^{32}$ Wyjaśnił, że w stanie naturalnym człowiek jest niewinny jak dziecko, cieszy się życiem, otaczającą przyrodą pól i lasów, którą czci jak bóstwo i jest ufny. Gdy rości sobie prawa do ziemi i bierze ją „,na procent lenna” przechodzi w stan społeczny, który jest „w swej istocie kontynuacją wojny wszystkich przeciwko wszystkim.” Pestalozzi uogólnił ,jako dzieło natury, jako zwierzę jestem doskonały; jako dzieło samego siebie dążę do doskonałości; jako dzieło rodzaju próbuję pozostać na etapie, w którym doskonałość samego siebie nie jest możliwa."33

Jeśli chodzi o polską myśl naukową, trzeba przypomnieć Jana Śniadeckiego, który interesował się filozofią przyrody. Był zwolennikiem indukcyjnego badania praw przyrody. Wyjaśnił, że w przyrodzie panuje porządek - dzieło Mądrości Najwyższej. ${ }^{34}$ Jego brat Jędrzej Śniadecki (filozof przyrody) ${ }^{35}$ podjął próbę wyjaśnienia wzajemnej zależności organizmów (jestestw) ${ }^{36}$ w systemie natury. Pisał, że człowiek jest największym wśród stworzeń zabójcą. ${ }^{37}$ „Chciwość, zazdrość, okrucieństwo, a nade wszystko ambicyja jest najsilniejszą sprężyną jego zniszczenia i sama jedna jest dostateczną tamą wstrzymującą i jego ciągłe doskonalenie się." ${ }^{38}$ Śniadecki krytycznie ocenił ingerencję człowieka w środowisku naturalnym. Podkreślił, że harmonijnie relacje człowieka z przyrodą są warunkiem zdrowego życia. Człowiek stanowi integralną część systemu przyrody, z którego należy czerpać mądrość (prawo natury), kształtując poszczególne sfery życia społecznego. Jędrzej Śniadecki postulował, aby redukować antynomię natury i kultury. ${ }^{39}$

32 J.H. Pestalozzi, Moje badania nad udziałem natury w rozwoju rodzaju ludzkiego, Wrocław 1984, s. 66-115.

33 Tamże, s. 120.

34 J. Śniadecki, Geografia czyli opisanie matematyczne i fizyczne Ziemi, [w:] tegoż, Wybór pism naukowych, Kraków 1954, s. 426.

35 E. M. Mystkowski, Jędrzej Śniadecki jako przyrodnik, Odbitka z „Pediatrii Polskiej" 1938, t. XVIII, z. 7-8, s. 1-3.

${ }^{36}$ L. Świerzawski, Jędrzej Śniadecki jego żywot, naukowe i społeczne stanowisko, Petersburg 1900, s. 27.

37 B. Rejchman, Jędrzej Śniadecki i Darwin. Przyczynek do dziejów piśmiennictwa naukowego polskiego, odbitka z czasopisma „Niwa”, Warszawa 1874, s. 7.

38 J. Sniadecki, Wybór pism naukowych i publicystycznych, Kraków 1952, s. 220.

39 J. Strojnowski, Psychofizjologia Jędrzeja Śniadeckiego, Wrocław 1968, s. 61. 
W dziele pt. Teoria jestestw organicznych wyjaśnił związki organicznej i nieorganicznej sfery przyrody (za pomocą metod badań stosowanych w naukach biologiczno-chemicznych). Został uznany za prekursora ekologii w Polsce także dlatego, że wyjaśnił znaczenie Słońca, ${ }^{40}$ jako źródła procesów organicznych. Poza tym uzasadnił ${ }^{41}$ społeczno-przyrodnicze uwarunkowania rozwoju organizmu ludzkiego. Twierdził, że przyroda stanowi uporządkowany zbiór jednostek i gatunków (ściśle ze sobą powiązanych) rozwijających się według zasady entropii - w układzie jednokierunkowym (tzn. układ ciał nie powtarza się w całości). ${ }^{42}$ Był zwolennikiem wieloaspektowego ujmowania problemów naukowych (badania interdyscyplinarne).

Żyjącego w XVIII wieku księdza Jana K. Kluka uznano za prekursora polskiej sozologii ${ }^{43}$ nie tylko dlatego, że wyznał „,nie masz skarbu większego nad przyrodę ojczystą", ale także dlatego, że był badaczem przyrody, ${ }^{44}$ który wiedział, jak ją ochraniać. Kluk dostrzegł wartość estetyczno-rekreacyjną leśnych zasobów naturalnych. Ponadto jest autorem pierwszych podręczników ${ }^{45}$ przyrodniczych (historii naturalnej) napisanych w języku polskim. Przedsięwzięcie Kluka było pionierskie oraz trudne w realizacji, ponieważ w cezurze jego życia - w Rzeczypospolitej poza Collegium Nobilium przedmiotów przyrodniczych nie nauczano. ${ }^{46}$

Środowisko naturalne - zwłaszcza przyrody ojczystej - stało się przedmiotem polskiej twórczości w okresie międzypowstaniowym (romantyzm).${ }^{47}$ Poetycka estyma dla przyrody Tatr, szlacheckiego za-

${ }^{40}$ L. Szyfman, Jędrzej Śniadecki przyrodnik - filozof, Warszawa 1960, s. 67 i nast.

41 L. Chrzęściewski, Jędrzej Śniadecki. Życie i dzieło, Kraków 1978, s. 112.

42 J. Śniadecki, Wybór pism... dz. cyt, s. 442.

43 Termin ,sozologia" etymologicznie wywodzi się z j. greckiego od słowa sodzo, które znaczy ochraniać, ocalać, ratować. Do polskiego słownika naukowego pojęcie wprowadził W. Goetel jako naukę o ochronie przyrody. Zob. J. M. Dołęga, Ekofilozofia i sozologia w edukacji XXI wieku, „Zarządzanie i Edukacja” 2007 nr 50, s. 77.

44 G. Brzęk, Krzysztof Kluk, Lublin 1977, s. 158-188.

45 Cz. Majorek, Księgi szkolne Komisji Edukacji Narodowej, Warszawa 1975, s. 70-71.

46 Tamże, s. 30.

47 M.in. twórczość poetycka J. I. Kraszewskiego, S. Goszczyńskiego, B. Z. Stęczyńskiego, L. Bierkowskiego, W. Pola, A. Mickiewicza, J. Słowackiego. 
ścianka (środowisko wiejskie) pełniła funkcję patriotyczną gdy polska kultura walczyła o przetrwanie w latach niewoli narodowej. Natomiast w okresie pozytywizmu jednoczono siły społeczne w celu budowania zakładów leczniczych (leczenie sanatoryjne), ${ }^{48} \mathrm{w}$ których zatrudnieni lekarze realizować mają leczenie balneologiczne. Według Józefa Dietla, zdrojowe wody są cennym środkiem leczniczym, ze względu na walor prewencyjny. ${ }^{49}$ Organizm ludzki ma właściwości samolecznicze w optymalnych warunkach życia. ${ }^{50}$

J. Dietl podkreślił walor terapeutyczny środowiska naturalnego w leczeniu chorych, zwłaszcza gdy ,zakład położony na romantycznem leśnem urwisku, jakby ręką czarodzieja $\mathrm{z}$ łona ziemi wyprowadzony, tak piękny i zachwycający sprawia widok", ${ }^{51}$ że pobyt w zdrojowiskach górskich sprawia „iż źrzódła wód lekarskich są zarazem źrzódłami naszej pomyślności." 52 Tym bardziej, gdy są to dary przyrody ojczystej. O leczniczych walorach środowiska naturalnego w Tatrach ${ }^{53}$ pisał także Tytus Chałubiński. Natomiast Stanisław Witkiewicz ${ }^{54}$ w swojej twórczości eksponował życiodajny wpływ środowiska naturalnego na zdrowie ludzkie ,tu człowiek odpoczywa, a pesymizm zostaje pobity"55, podobnie jak (m. in.) Jan Kasprowicz ${ }^{56}$, Kazimierz Przerwa Tetmajer, Władysław Reymont, Stefan Żeromski. ${ }^{57}$

48 W. Hensel, J. Pazdur (red.), Historia kultury materialnej Polski $w$ zarysie, t. VI, Wrocław 1974, s. 464.

49 J. Dietl, Krynica w Karpatach galicyjskich położona, opisana pod względem historycznym, topograficznym, klimatycznym, botanicznym, geologicznym i lekarskim, Kraków 1857, s. 39-207.

50 J. Dietl, Źrzódła lekarskie w Szczawnicy, Kraków 1858, s. 59; Por. S. Szpilczyński, Nauki medyczne, [w:] B. Suchodolski (red.), Historia nauki polskiej, t. III 17951862, Wrocław 1977, s. 606.

51 J. Dietl, Źrzódła lekarskie w Iwoniczu, Kraków 1858, s. 4.

52 J. Dietl, Uwagi nad zdrojowiskami krajowemi ze względu na ich skuteczność, zastosowanie i urzadzenie, Kraków 1858, cz. 1, s. 3-363.

53 T. Chałubiński, Sześć dni w Tatrach wycieczka bez programu, Kraków 1988, s. 76.

54 Ojciec Stanisława Ignacego Witkiewicza.

55 S. Witkiewicz, Zakopane w zimie. Tatry w śniegu, Gdańsk 1991, s. 1.

56 J. Kasprowicz, Pory roku, Zakopane 1995, s. 21; J. Kasprowicz, Z Tatr, Kraków 1976, s. 5 i nast.

57 S. Żeromski, Puszcza jodłowa, Kielce 1889, s. 44. 
W okresie Drugiej Rzeczypospolitej środowisko naturalne było kategorią ekologiczną w literaturze naukowej. W licznych publikacjach (m.in. Jana Gwalberta Pawlikowskiego, Mariana Sokołowskiego) rozważano problem wychowania do zdrowych relacji ze środowiskiem przyrody, kształtowania świadomości ekologicznej, ${ }^{58}$ wypracowania ustawodawstwa ochrony przyrody ${ }^{59}$ (umożliwiającego chłonienie dóbr naturalnych środowiska niezależnie od woli właściciela lub praw użytkowania), realizowania wychowania ekologicznego w szkole ${ }^{60}$ - za pomoca przygotowanych do tego celu podręczników. ${ }^{61} \mathrm{Na}$ łamach czasopism przeważały artykuły dotyczące ochraniania poszczególnych roślin, zwierząt, rezerwatów leśnych. Publikowano informacje bieżące o odczytach popularyzujących wiedzę przyrodniczą oraz dotyczącą ochrony środowiska naturalnego, także informacje o dyskusjach naukowych podczas spotkań konferencyjnych i przepisy prawne (ustawodawstwo polskie i zagraniczne).

Mimo bogatej literatury - zwłaszcza na łamach periodyków naukowych i popularnonaukowych w okresie Drugiej Rzeczypospolitej wychowanie ekologiczne w procesie kształcenia dzieci i młodzieży było realizowane jedynie hasłowo $-\mathrm{w}$ ramach lekcji z przyrody i geografii. Dopiero po II wojnie światowej - w 1974 roku - w polskich szkołach wyodrębniono $\mathrm{w}$ programie nauczania działy o ochronie środowiska naturalnego. Natomiast od 1978 roku w programie szkoły dziesięcioletniej, w klasach I-III wprowadzono nowy przedmiot „środowisko społeczno-przyrodnicze".

Środowisko - w ujęciu Danuty Cichy - jest „układem stosunków przyrodniczych, ekonomicznych, społecznych i kulturalnych, w któ-

\footnotetext{
58 J.G. Pawlikowski, O lice ziemi. Wybór pism, Warszawa 1938, s. 91; tenże, Prawodawstwo ochronne (odbitka ze „Skarbów Przyrody”), Warszawa 1932, s. 5; tenże, O celach $i$ środkach ochrony przyrody, Zakopane 1920, s. 5 i nast.

59 J.G. Pawlikowski, Rozbudowa prawnych podstaw ochrony przyrody w Polsce (odbitka z „Ochrony Przyrody” 1934, z. 14), Kraków 1935, s. 1; tenże, Prawo ochrony przyrody, Kraków 1927, s. 121.

${ }^{60}$ M. Sokołowski, O wprowadzeniu ochrony przyrody do nauczania szkolnego (odbitka z „Ochrony Przyrody” 1925, z. 5.), Kraków 1925, s. 4.

${ }_{61}$ M. Sokołowski, Ochrona przyrody w szkole. Wartość idei ochrony przyrody $w$ wychowaniu i kształceniu młodzieży, Kraków 1927, s. 58 i nast.
} 
rych żyje człowiek. Od stosunków panujących w środowisku zależy egzystencja społeczeństw." ${ }^{12}$ Środowisko naturalne osoby ludzkiej ${ }^{63}-$ jak już wspomniałam - jest kategorią ekologiczną. Tworzy je zarówno płaszczyzna przyrodnicza (w której jest pokarm), jak również społeczeństwo (w którym jednostka żyje) oraz sama osoba stanowi dla siebie środowisko. Zatem edukację ekologiczną trzeba realizować interdyscyplinarnie i wieloaspektowo - począwszy od obszaru relacji intrapersonalnej (praca nad sobą), następnie w obszarze interpersonalnym oraz w obszarze relacji z przyroda. ${ }^{64}$ Edukacja ekologiczna jest procesem psychologiczno-pedagogicznego oddziaływania na człowieka w celu ukształtowania świadomości ekologicznej, moralnej odpowiedzialności za jakość środowiska życia. ${ }^{65}$ Świadomość ekologiczna to „system wiedzy, poglądów i przekonań na temat środowiska przyrodniczego. Umożliwia postrzeganie związków między stanem i charakterem środowiska, a warunkami i jakością życia człowieka."66 Jako obszar, świadomości społecznej odniesionej do środowiska przyrodniczego, którego człowiek stanowi integralną część - implikuje wiedzę, nastawienia, emocje. ${ }^{67}$ Stanowi część składową koncepcji rozwoju zrównoważonego, ${ }^{68}$ który pozwoli człowiekowi harmonijnie funkcjonować w środowisku przyrody.

62 D. Cichy, Dylematy ksztatcenia dorostych dla wdrażania zrównoważonego rozwoju, [w:] J. W. Czartoszewski, E. Grott (red.), Problemy XXI wieku uwarunkowania spoteczno-pedagogiczne wychowania do zrównoważonego rozwoju, Warszawa 2007, s. 9.

${ }_{63}$ M. Wyrostkiewicz, Ekologia ludzka. Osoba i jej środowisko z perspektywy teologiczno-moralnej, Lublin 2007, s. 51 - 53.

${ }^{64}$ Por. szerzej: E. Wolter, Historyczne aspekty edukacji ekologicznej w Polsce, Warszawa 2006, s. 24.

65 I. Kozłowska, Edukacja ekologiczna studentów, [w:] Problemy Dydaktyki i Wychowania w Akademii Rolniczej w Poznaniu, Poznań 1997, s. 13.

${ }^{66}$ T. Wieczorek, Edukacja i doradztwo rolnicze wobec wyzwań zrównoważonego rozwoju, [w:] Doradztwo rolnicze w stymulowaniu i wspieraniu przemian zachodzacych w polskim rolnictwie - materiały konferencyjne, Poznań 1998, s. 261.

67 L. Tuszyńska, Edukacja ekologiczna dla nauczycieli i studentów, Warszawa 2006, s. 7.

68 E. Szczepaniec-Cięciak, Relacje między pedagogika a ekologia na przykładzie nauczania i wychowania dla zrównoważonego rozwoju, [w:] S. Palka (red.), Pogranicza pedagogiki i nauk pomocniczych, Kraków 2004, s. 253. 


\section{EDUKACJA EKOLOGICZNA DLA PEDAGOGÓW}

Edukacja ekologiczna (środowiskowa) jest wyzwaniem dla pedagogów ${ }^{69}$ - w redukowaniu antynomii natury i kultury, kształtowaniu zdrowej $^{70}$ populacji ludzkiej jako integralnej części środowiska przyrody; wychowywaniu do zdrowej samorealizacji w środowisku ${ }^{71}$ społeczno-przyrodniczym „sięgania do źródeł ludzkiej wrażliwości etycznej (...) wychowania jak najwszechstronniejszej osobowości"72, która jest osobowością pełną, altruistyczną, wartościującą etycznie ${ }^{73}$ - na rzecz zrównoważonego rozwoju. Dla pedagogiki jako dyscypliny naukowej, która integruje ,wiedzę innych nauk skupiających się fragmentarycznie na zjawisku wychowania i kształcenia, odpowiada (...) na podstawowe pytania o sens życia" ${ }^{74}$ - znaczenie ma środowisko wychowawcze, w skład którego wchodzą: rodzina, grupy rówieśnicze, społeczność lokalna ('środowisko lokalne), instytucje wychowania bezpośredniego (przedszkola, szkoły) oraz instytucje wychowania pośredniego - które wpływają na rozwój tożsamości indywidualnej i społecznej (wspólnotowej) w ,animowaniu (...) aktywnością ludzi w ramach dobra społecznego" 75 - jakim jest zdrowe środowisko życia.

\footnotetext{
${ }^{69}$ A. Gromkowska-Melosik, Pedagogika ekologiczna, [w:] Z. Kwieciński, B. Śliwerski (red.), Pedagogika podręcznik akademicki, Warszawa 2004, t. 1, s. 425 i nast.; por. M. Nowak, Teorie i koncepcje wychowania, Warszawa 2008, s. 202 i nast.; por. N. Wolański, Ekologia człowieka, t. 2: Podstawy ochrony środowiska i zdrowia człowieka. Ewolucja i dostosowanie biokulturowe, Warszawa 2008, s. 473 i nast.

70 Z. Paśniewska-Kuć, Humanistyczna terapia rozwojowa. Wzmożona pobudliwość psychiczna i nerwice w perspektywie osobowego rozwoju, Warszawa 2010, s. 34.

71 D. Cichy, Środowiskowy projekt edukacyjny - szkolna monografia „,Nasza miejscowość”, „Edukacja Biologiczna i Środowiskowa. Kwartalnik dla nauczycieli” 2009, nr 3 (31), s. 41 i nast.

72 A. Solak, ,Myślenie wedlug wartości” a wychowanie, [w:] tenże (red.), Przyszłość wychowania, Tarnów 2001, s. 53, 65.

73 A. Solak, Człowiek $i$ jego wychowywanie. Zagadnienia wybrane, Wydawnictwo Diecezji Tarnowskiej, Tarnów 2004, s. $10-11$.

74 S. Chrobak, Podstawy pedagogiki nadziei. Współczesne konteksty w inspiracji personalistyczno-chrześcijańskiej, Warszawa 2009, s. 313.

75 Z. Babicki, Lider i animacja społeczna na terenie parafii, „Pedagogika społeczna” 2007 , nr 3, s. 82.
} 


\section{PODSUMOWANIE}

Edukacja ekologiczna (środowiskowa) w Polsce jest składnikiem edukacji obywatelskiej - ma związek z promowaniem wartości i postaw humanistycznych, zapobieganiem patologiom społecznym ${ }^{76}-\mathrm{w}$ epistemologicznej otwartości na wrażliwość ekologiczną osoby ludzkiej i realizowaniu celów „Narodowej Strategii Edukacji Ekologicznej” wychowania dla zrównoważonego rozwoju społeczno-przyrodniczego.

\section{BIBLIOGRAFIA}

Agapow L., Kładna A., Kruk J., Feruszewski R., Ekologia człowieka, Szczecin 1998.

Babicki Z., Lider i animacja społeczna na terenie parafii, [w:] „Pedagogika społeczna" (Zespół Pedagogiki Społecznej Komitetu Nauk Pedagogicznych PAN „Pedagogium”), Warszawa 2007.

Brzęk G., Krzysztof Kluk, Wydanie drugie rozszerzone i uzupełnione, Lublin 1977.

Chałubiński T., Sześć dni w Tatrach wycieczka bez programu, Kraków 1988.

Chrobak S., Podstawy pedagogiki nadziei. Wspótczesne konteksty w inspiracji personalistyczno-chrześcijańskiej, Warszawa 2009.

Chromiński Z., Malinowski A., Ekologia człowieka, Warszawa 2001.

Cichy D., Dylematy ksztatcenia dorostych dla wdrażania zrównoważonego rozwoju, [w:] J. W. Czartoszewski, E. Grott (red. nauk.), Problemy XXI wieku uwarunkowania społeczno-pedagogiczne wychowania do zrównoważonego rozwoju, Warszawa 2007.

Cichy D., Środowiskowy projekt edukacyjny - szkolna monografia „Nasza miejscowość”, w: „Edukacja Biologiczna i Środowiskowa. Kwartalnik dla nauczycieli" 2009.

${ }^{76}$ B. Kałdon, Środowiskowe i osobowościowe uwarunkowania przynależności młodzieży do subkultur, [w:] B. Kałdon, J. Kahlan, A. Fidelus (red.), Diagnostyka i rozwiazywanie problemów psychospołecznych dzieci i młodzieży, Sandomierz-Warszawa 2009, s. 43 i nast. 
Chrzęściewski L., Jędrzej Śniadecki. Życie i dzieło, Kraków 1978.

Dewey J., Jak myślimy?, w: S. Wołoszyn (wybór i opr.), Źródła do dziejów wychowania i myśli pedagogicznej, Tom III księga pierwsza: Myśl pedagogiczna w XX wieku, Wydanie drugie zmienione, Kielce 1998.

Dietl J., Krynica w Karpatach galicyjskich położona, opisana pod względem historycznym, topograficznym, klimatycznym, botanicznym, geologicznym i lekarskim, Kraków 1857.

Dietl J., Uwagi nad zdrojowiskami krajowemi ze względu na ich skuteczność, zastosowanie i urzqdzenie, Kraków 1858.

Dietl J., Źródła lekarskie w Iwoniczu, Kraków 1858.

Dietl J., Źródta lekarskie w Szczawnicy, Kraków 1858.

Dołęga J. M., Ekofilozofia i sozologia w edukacji XXI wieku, [w:] „Zarządzanie i Edukacja” 2007, nr 50.

Górnicki Ł., Dworzanin polski, Wrocław 2004.

Gromkowska-Melosik A., Pedagogika ekologiczna, [w:] Z. Kwieciński, B. Śliwerski (red. nauk.), Pedagogika podręcznik akademicki, Warszawa 2004, t. 1.

Hensel W., Pazdur J. (red.), Historia kultury materialnej Polski w zarysie. Tom 1: od VII do XII wieku pod red. M. Dembińskiej i Z. Podwińskiej, Wrocław 1978.

Hensel W., Pazdur J. (red.), Historia kultury materialnej Polski w zarysie, Tom VI: od 1870 do 1918 pod red. B. Baranowskiego, J. Bartysia, T. Sobczaka, Wrocław 1974.

Ingarden R., Ksiażeczka o człowieku, Kraków 2009.

Jethon Z., Ekologia czlowieka $w$ wychowaniu fizycznym i sporcie, Wrocław 1994.

Kałdon B., Środowiskowe i osobowościowe uwarunkowania przynależności młodzieży do subkultur, w: B. Kałdon, J. Kahlan, A. Fidelus (red.), Diagnostyka i rozwiązywanie problemów psychospołecznych dzieci i młodzieży, Sandomierz - Warszawa 2009.

Kasprowicz J., Pory roku (wybór R. Loth), Kraków 1995.

Kasprowicz J., Z Tatr (opr. R. Loth), Kraków 1976.

Komeński J. A., Wielka dydaktyka, Warszawa - Lwów 1935. 
Kozłowska I., Edukacja ekologiczna studentów, [w]: „Problemy Dydaktyki i Wychowania w Akademii Rolniczej w Poznaniu”, Poznań 1997.

Majorek C., Księgi szkolne Komisji Edukacji Narodowej, Warszawa 1975.

Mystkowski E. M., Jędrzej Śniadecki jako przyrodnik, Odbitka z „Pediatrii Polskiej" 1938.

Nowak M., Teorie i koncepcje wychowania, Warszawa 2008.

Parandowski J., Rousseau. Szkic literacko-filozoficzny, Odbitka z „Przeglądu”, Lwów 1913.

Paśniewska - Kuć Z., Humanistyczna terapia rozwojowa. Wzmożona pobudliwość psychiczna i nerwice w perspektywie osobowego rozwoju, Warszawa 2010.

Pawlikowski J. G., O celach $i$ środkach ochrony przyrody, Zakopane 1920.

Pawlikowski J. G.,. O lice ziemi Wybór pism, Warszawa 1938.

Pawlikowski J. G., Prawo ochrony przyrody, Kraków 1927.

Pawlikowski J. G., Prawodawstwo ochronne (odbitka ze „Skarbów Przyrody"), Warszawa 1932.

Pawlikowski J. G., Rozbudowa prawnych podstaw ochrony przyrody w Polsce (odbitka z „Ochrony Przyrody” 1934), Kraków 1935.

Pestalozzi J. H., Moje badania nad udziałem natury w rozwoju rodzaju ludzkiego, Wrocław 1984.

Pieter J., Stownik psychologiczny, Wydanie drugie, Katowice 2004.

Rej M., Żywot czlowieka poczciwego (opr. J. Krzyżanowski), Wrocław 2003.

Rejchman B., Jędrzej Śniadecki i Darwin, przyczynek do dziejów piśmiennictwa naukowego polskiego, Warszawa 1874.

Rousseau J. J., Emil czyli o wychowaniu (tłum. W. Husarski), Lwów - Warszawa 1930, cz. 1.

Rousseau J. J., Emil czyli o wychowaniu (tłum. E. Zieliński), Lwów - Warszawa 1933, cz. 2.

Rousseau J. J., O umowie społecznej (tłum., opr. M. Starzewski), Kraków 1927. 
Rousseau J. J., Wybór tekstów pedagogicznych (opr. H. Pohoska), Warszawa 1949.

Stownik terminologiczny informacji naukowej, Wrocław 1979.

Sokołowski M., Ochrona przyrody w szkole. Wartość idei ochrony przyrody w wychowaniu i ksztatceniu młodzieży, Kraków 1927.

Sokołowski M., O wprowadzeniu ochrony przyrody do nauczania szkolnego (odbitka z „Ochrony Przyrody” 1925), Kraków 1925.

Solak A., Człowiek i jego wychowywanie. Zagadnienia wybrane, Tarnów 2004.

Solak A., Myślenie wedtug wartości a wychowanie, [w:] A. Solak (red. nauk.), Przyszłość wychowania, Tarnów 2001.

Strojnowski J., Psychofizjologia Jędrzeja Śniadeckiego, Wrocław 1968.

Szacki J., Historia myśli socjologicznej. Wydanie nowe, Warszawa 2002 .

Szczepaniec-Cięciak E., Relacje między pedagogika a ekologiq na przykładzie nauczania $i$ wychowania dla zrównoważonego rozwoju, w: S. Palka (red.), Pogranicza pedagogiki i nauk pomocniczych, Kraków 2004.

Szczepański J., Sprawy ludzkie, Wydanie trzecie rozszerzone, Warszawa 1984.

Szczepański J., Wptyw kultury na życie społeczne, [w:] H. Mielicka (wstęp i opr.), Socjologia wychowania. Wybór tekstów, Kielce 2000.

Szpilczyński S., Nauki medyczne, [w:] B. Suchodolski (red.), Historia nauki polskiej. Tom III 1795 - 1862, Wrocław 1977.

Szyfman L., Jędrzej Śniadecki przyrodnik - filozof, Warszawa 1960.

Śniadecki J., Geografia czyli opisanie matematyczne i fizyczne Ziemi, [w:] J. Śniadecki, Wybór pism naukowych, Kraków 1954.

Śniadecki J., Wybór pism naukowych i publicystycznych (opr. B. Skarżyński), Kraków 1952.

Świerzawski L., Jędrzej Śniadecki jego żywot, naukowe i społeczne stanowisko, Petersburg 1900.

Tuszyńska L., Edukacja ekologiczna dla nauczycieli i studentów, Warszawa 2006. 
Wieczorek T., Edukacja i doradztwo rolnicze wobec wyzwań zrównoważonego rozwoju, [w:] Doradztwo rolnicze w stymulowaniu i wspieraniu przemian zachodzących $\mathrm{w}$ polskim rolnictwie - materiały konferencyjne, Poznań 1998.

Wierzbicki Z. T., Ekologia człowieka a sozologia, Wrocław 1982.

Witkiewicz S., Zakopane w zimie. Tatry w śniegu, Gdańsk 1991.

Wolański N., Ekologia człowieka. Tom 1: Podstawy ochrony środowiska i zdrowia czlowieka. Wrażliwość na czynniki środowiska i biologiczne zmiany przystosowawcze, Warszawa 2008.

Wolański N., Ekologia człowieka. Tom 2: Podstawy ochrony środowiska i zdrowia człowieka. Ewolucja i dostosowanie biokulturowe, Warszawa 2008.

Wolter E., Historyczne aspekty edukacji ekologicznej w Polsce, Warszawa 2006.

Wyrostkiewicz M., Ekologia ludzka. Osoba i jej środowisko z perspektywy teologiczno-moralnej, Lublin 2007.

Znaniecki F., Metoda socjologii, Warszawa 2008.

Żeromski S., Puszcza Jodłowa, Kielce 1889.

Żmuda S., Zarys ekologii człowieka, Kraków 1983. 